\title{
O literackich i translatorskich potyczkach Wiktora Woroszylskiego z cenzurą ( Dziennikami w tle)
}

Beata Pawletko

(Uniwersytet Śląski w Katowicach)

Wiktor Woroszylski był jednym z największych znawców literatury rosyjskiej, kompetentnym komentatorem spraw rosyjskich. Można powiedzieć, że szeroko pojęta rusycystyka należała do najważniejszych obszarów jego zainteresowań i aktywności twórczej. Woroszylski pozostawił po sobie nie tylko książki biograficzne o pisarzach rosyjskich, ale również ogromną liczbę przekładów, przedmowy, posłowia do redagowanych i współredagowanych wyborów wierszy i antologii oraz teksty popularyzatorskie (najczęściej okolicznościowe) przeznaczone do różnych czasopism. Liczne ślady odwołań do bieżącej problematyki rosyjskiej znajdziemy w felietonach pisanych do kwartalnika „Więź” (zgromadzonych następnie w tomach publicystyki: Na kurczacym się skrawku, $W$ dżungli wolności, Pozwólcie nam się cieszyc) oraz w zapiskach diarystycznych (zebranych w trzech tomach Dzienników). Przez dziesięciolecia autor Snów pod śniegiem niestrudzenie starał się promować literaturę i kulturę rosyjską, walczyć ze stereotypami, z utożsamianiem polityki prowadzonej przez imperium sowieckie z oczekiwaniami jego mieszkańców czy z działalnością literatów i ludzi kultury. Dzięki swoim kontaktom zdobywał materiały do książek biograficznych, ale był też na bieżąco informowany o aktualnej sytuacji społeczno-politycznej, co pomagało mu formułować trafne tezy i prognozy dotyczące zarówno Związku Sowieckiego, jak i relacji polsko-rosyjskich. Zwracają uwagę jego wyważone opinie, ich przenikliwość wynikająca $z$ wieloaspektowej perspektywy badawczej. W celnym ujmowaniu i ocenie bieżących wydarzeń Woroszylskiemu pomagała pogłębiona wiedza na temat literatury i kultury rosyjskiej, dziejów Rosji czy znajomość pewnych mechanizmów zachowań i działań, w tym aparatu represji i cenzury. 
Niezaprzeczalna aktywność Woroszylskiego w tej dziedzinie mogłaby sugerować, że „sprawy rosyjskie” to bezpieczna przystań, że autor Literatury zawsze mógł liczyć na publikacje wynikające - jak to określił Jerzy Stempowski - z „przywilejów rusycystyki”. Jednak rację ma Andrzej Friszke, gdy pisze, że

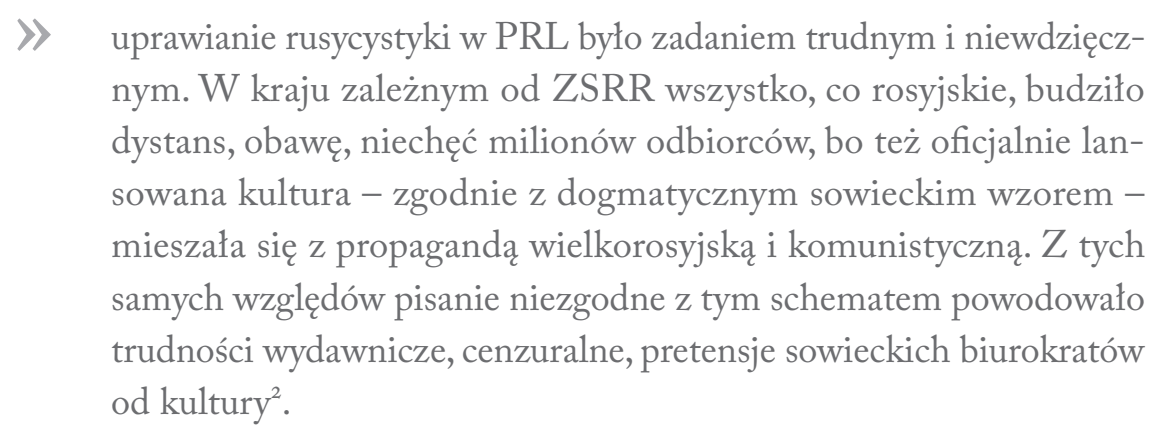

Słowa te znajdują potwierdzenie w wielu wpisach diarystycznych Woroszylskiego. Czytając Dzienniki, których publikacja skłania nie tylko do ponownego odczytania jego utworów, ale także szerszego, kontekstowego ujęcia przedsięwzięć i dokonań translatorskich, trudno oprzeć się wrażeniu, że z chwilą powstania Dziennika węgierskiego i opublikowaniem zaledwie jego fragmentów dla pisarza zaczyna się nowy etap, w którym ważną rolę coraz częściej odgrywać będą potyczki z cenzurą. Oczywiście, znając realia rosyjskie, studiując materiały do biografii o Michaile Sałtykowie-Szczedrinie oraz Aleksandrze Puszkinie, Woroszylski tak głęboko poznał mechanizmy działania cenzury carskiej, że właściwie nie mogło być mowy o paraliżującym strachu przed cenzurą peerelowską, z którą wręcz starał się prowadzić grę-walkę, polegającą na przykład w twórczości oryginalnej (zob. zbiory opowiadań Okrutna grwiazda i Historie czy powieść Literatura) na pewnej „obsesyjności tematycznej”", natarczywym powracaniu do niektórych wątków, motywów, postaci, fragmentów innych utworów ${ }^{4}$. Ponadto "strategia obejścia” zawiera formalne składniki dzieła - od kwalifikacji gatunkowej poczynając, a na typie narracji kończąc.

1 Cyt. za: A. Friszke, Wiktor Woroszylski. Polityka i literatura, w: W. Woroszylski, Dzienniki 1953-1982, t. 1, Warszawa 2017, s. 47.

2 Ibidem, s. 48.

3 W. Woroszylski, Dzienniki 1983-1987, t. 2, Warszawa 2018, s. 34. Dalej stosuję następujące skróty na oznaczenie tytułów książek Woroszylskiego i prac (współ)redagowanych przez niego, po skrócie podając numer strony: A = W. Dąbrowski, A. Mandalian, W. Woroszylski, Antologia nowoczesnej poezji rosyjskiej 1880-1967, t. 1-2, Wrocław 1971; Dz 1 = Dzienniki 1953-1982; Dz 2 = Dzienniki 1983-1987, Warszawa 2018; KzP = Kto zabit Puszkina, Warszawa 2004; S = Sny pod śniegiem, Warszawa 1963.

4 Więcej na ten temat zob. J. Kandziora, „Literatura” Wiktora Woroszylskiego - poetycka formuta prozy autobiograficznej, „Pamiętnik Literacki” 1992, z. 1, s. 40.

5 Zob. J. Hobot, Gra z cenzurą w poezji Nowej Fali (1968-1976), Kraków 2000, s. 53. 
Widoczne jest to między innymi w przypadku dwóch książek biograficznych Snów pod śniegiem oraz Życia Majakowskiego, wydanych po raz pierwszy w latach sześćdziesiątych. W Dziennikach znajdziemy uwagi na temat ich recepcji w Polsce i za granicą (szczególnie dotyczy to biografii autora Obtoku w spodniach), prac nad wariantem scenicznym Życia Majakowskiego ${ }^{6}$ oraz prób wznowienia obu książek w obiegu oficjalnym, czego uda się dokonać w latach osiemdziesiątych, choć nie bez trudności ze strony wydawców. Wznowienie Snów pod śniegiem, podobnie zresztą jak druga, uzupełniona (bez ingerencji cenzury) edycja Życia Majakowskiego, nastąpi w 1984 roku, to jest po przełomie lat siedemdziesiątych i osiemdziesiątych znamionującym zakaz publikacji,jakim Woroszylski był objęty w związku ze swoją intensywną działalnością opozycyjną. Strategia gry z cenzurą opierała się między innymi na rozproszeniu publikacji po różnych oficynach i domach wydawniczych, „montowaniu” tomików z materiałów leżących w wydawnictwach i tych powstających na bieżąco, ale również na specyficznie pisanej prozie. Ważne w tym kontekście jest wyznanie Woroszylskiego z wywiadu przeprowadzonego przez Joannę Szczęsną: „W gruncie rzeczy nigdy nie byłem prawdziwym prozaikiem i nie stałem się nim także w tej książce [tj. Snach pod śniegiem - B. P.]. Pisałem ją jako wiersz, oczywiście bardzo specyficzny". Nie ma wątpliwości, że zrytmizowanie, liryzacja prozy nie ułatwiały zadania cenzorom. Nierzadko negocjacje wydawnicze wymagały jednak pójścia na kompromis, rezygnacji ze złożonej wcześniej książki na rzecz włączenia do planu wydawniczego na dany rok innej publikacji. Tak stało się w przypadku drugiej edycji Snów pod śniegiem, która ukazała się nakładem Wydawnictwa Literackiego. Nastąpiło to kosztem tomu opowiadań Historie, których losy - jak podkreśla Woroszylski we wpisie datowanym na I5 lutego I983 roku - są szczególnie zawiłe:

\ pierwsze opowiadania powstały w latach sześćdziesiątych, po raz pierwszy złożyłem maszynopis (naturalnie niepodobny do obecnego) chyba w maju 1968 [...], potem książka zmieniała kształt i narastała

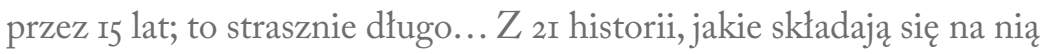
obecnie, I3 wchodziło do wariantu, jaki przedłożyłem wydawnictwu I5 lat temu $[\ldots]$ (Dz 2, s. 34).

Ostatecznie zbiór ukazał się dopiero w 1987 roku nakładem Czytelnika. Sny pod śniegiem zwracają uwagę odbiorcy właśnie charakterystycznym rytmem oraz

6 Pokaz dla cenzury przedstawienia Majakowski nie żyje w reżyserii Jerzego Markuszewskiego w STS-ie odbył się 15 lutego 1967 roku. Trzy dni później miała miejsce premiera dla publiczności.

7 Jaw Rosji, Rosja we mnie. Wiktor Woroszylski w rozmowie z Joanną Szczesna, "Gazeta Wyborcza” z 6-8 kwietnia 1996 r., s. 10. Zob. również J. Kandziora, op. cit., s. 60. 
pierwszoosobową narracją. Przemawiając jako Sałtykow-Szczedrin, Woroszylski wykorzystuje istotne nie tylko z punktu widzenia dziewiętnastowiecznej Rosji aspekty biografii autora Dziejów perwnego miasta. Mowa o jego pełnej zaangażowania postawie i trosce o losy państwa rosyjskiego, realizowanej jednak w przewrotnym stylu. Sałtykow-Szczedrin dał się zapamiętać jako nieprzejednany wróg cenzury, którą określał mianem kagańca nakładanego psu - nie przeszkadza on wprawdzie szczekać i obwąchiwać, ale o gryzieniu można zapomnieć. Autor Szkicórw gubernialnych jako redaktor czasopisma „Otieczestwiennyje zapiski” (zamkniętego przez władze carskie w I884 roku na fali represji po zamachu na cara Aleksandra II) niejednokrotnie miał do czynienia $z$ cenzurą. Wiedział, że o wielu sprawach nie sposób pisać wprost i że konieczne jest wypracowanie języka ezopowego, pełnego niedomówień, ironii, podtekstów, zdawkowych kwestii. Mistrz satyry operował ponadto hiperbolą, aluzją, alegorią, co widoczne jest zwłaszcza w jego bajkach społeczno-politycznych (które Woroszylski miał za zadanie zgłębić jako doktorant), stanowiących summę poruszanych we wcześniejszych utworach satyrycznych wątków i tematów. Nic dziwnego, że te miniatury cieszyły się szczególnym powodzeniem wśród czytelników, przede wszystkim w kręgach inteligencji rosyjskiej. Woroszylski zapoznał się z twórczością Sałtykowa-Szczedrina jeszcze podczas studiów w Instytucie Literackim w Moskwie i po latach przyznał, że prawdziwym odkryciem był dla niego fakt, iż teksty, które powstały przecież kilkadziesiąt lat wcześniej, mogą odznaczać się taką aktualnością i siłą rażenia, jeśli chodzi o poruszaną w nich tematykę. Kwintesencją prowadzonej gry z cenzurą, ale i przewrotnym potwierdzeniem istnienia autocenzury, widzianych wszak z perspektywy XX wieku i polskiej powojennej rzeczywistości, są w Snach pod śniegiem następujące kwestie:

\section{\S Słychać nawet, że skasują cenzurę; i cóż ja pocznę? ona wszak ukształ- towała mój język; zamiast słów zastępczych mam na starość szukać prawdziwych? Nie ma obaw, ach, nie ma obaw (S, s. I3I). \\ W takiej chwili, perswadują cenzorzy, w takiej chwili, Michale Jewgra- fowiczu, taki artykuł. Gdy szykuje się prawie zupełna wolność. Kto wie, może za dwa miesiące bez mrugnięcia okiem puścimy (S, s. I3I).}

Zupełnie inaczej od strony formalnej wyglądała praca nad Życiem Majakowskiego, chociaż i tutaj myśli o cenzurze i jej przechytrzeniu zajmują sporo miejsca. W wywiadzie udzielonym Tatianie Bek Woroszylski wspomina, że komponując biografię Majakowskiego, bardzo starał się zachować kompromis między pisaniem nie pod dyktando cenzury a tym, by książka mogła się bez przeszkód ukazać. Postanowił, że będzie ona kolażem cytatów, fragmentów tekstów o Majakowskim, które 
zgromadził jeszcze podczas pobytu w Moskwie, i prac nad doktoratem o autorze Fletu kręgostupa, ale i przysłanych w późniejszym czasie przez Giennadija Ajgiego - wówczas zatrudnionego w Muzeum Majakowskiego. Pozornie zatem w książce nie ma żadnego komentarza odautorskiego, jednak dobór materiałów, ich zestawienie - co oczywiste - pozostawały przecież w gestii Woroszylskiego, którego celem nadrzędnym była chęć ukazania tragizmu egzystencji oraz dramatycznych konsekwencji dokonywania błędnych wyborów przez autora Łaźni $i^{8}$ Ponadto Ajgi przysłał tak wiele materiałów, że złożyły się one na dość obszerną książkę. W diariuszu pod datą 2I lutego I966 roku znajdziemy taką uwagę dotyczącą jej publikacji: „triumfalna chwila pierwszego dotknięcia grubej książki, której się jest autorem i na którą tak długo się czekało... Reszta dnia zatem pod znakiem obcowania z tym swoim dziecięciem" (Dz I, s. 197). Oprócz tego Woroszylski skrzętnie odnotowuje zarówno entuzjastyczne, jak i sceptyczne reakcje odbiorców na książkę. W chudych latach osiemdziesiątych przy okazji drugiego wydania rozmiar stanie się z kolei pretekstem do niepokoju, czy w sytuacji, kiedy wielu ludzi boryka się z problemami finansowymi, tak droga publikacja o radzieckim pisarzu ma szansę na dobre wyniki sprzedaży (Dz 2, s. 299). Podpisywane podczas spotkań autorskich, organizowanych w różnych miastach (najczęściej w kościołach), egzemplarze Snów pod śniegiem i Życia Majakowskiego przekonują jednak Woroszylskiego, że wznowienia cieszą się powodzeniem wśród czytelników, również rusycystów. Jest to ważne, tym bardziej że zarówno w okresie PRL-u, jak i później pisarz nieustannie będzie proszony na wieczorach i spotkaniach autorskich o wyjaśnienie, dlaczego zajmuje się Rosjanami. Gdy mowa o wznowieniach, warto wspomnieć o korekcie innej książki biograficznej, to jest Życia Sergiusza Jesienina, która po raz pierwszy ukazała się w I975 roku. Woroszylski robi korektę w obozie internowania w Jaworzu, ale wkrótce po jej wykonaniu zostaje przewieziony do Darłówka, co zdecydowanie komplikuje sprawę przekazania wydawnictwu maszynopisu z uwagami. Pod datą 26 maja 1982 roku znajdziemy na ten temat następującą adnotację:

\ W trakcie spaceru przedobiedniego Strachalski przekazal mi mesaż od inspektora Pawlaka (tak mu się tamten przedstawił), żebym wpadł w sprawie mojej książki. Nie zrobiłem tego, więc po pewnym czasie tamten sam się wyłonił i przyłapał mnie w trakcie kolejnego okrążenia. Powiedział, że przeczytał właśnie korektę Życia Sergiusza Jesienina (w połowie zeszłego tygodnia zostawiłem ją w sztabie ja-

8 Tomas Venclova podkreśla, że w ZSRR wiele z tych materiałów było zakazanych, więc ich wykorzystanie, ale i dostarczanie do Warszawy wiązało się ze sporym zagrożeniem. Więcej zob. Т. Венцлова, Пуикиин как неизбежный , другой, „Иностранная митература” 2009, № 4, http://magazines.russ.ru/inostran/2009/4/ ve5-pr.html (stan z 11 września 2018 r.). 
worzańskim, żeby na niedzielnym widzeniu zabrano do Warszawy; w sobotę przed naszym wyjazdem okazało się, że korekta poszła do KS MO; na widzeniu usłyszałem od Janki, że wydawnictwo nie mogło czekać i zesłało książkę do druku), bardzo mu się podoba i co ma teraz z tym zrobić. Odpowiedziałem, że nic, sprawa nieaktualna, książka jest w druku, ale ostatecznie jeżeli chce, może oddać do wydawnictwa (Dz I,s. 6II).

W obozie internowania Woroszylski pracuje również nad korektą ostatniej książki biograficznej Kto zabit Puszkina. Ona także znajdzie się na celowniku cenzury, przede wszystkim ze względu na prowokacyjny tytuł ${ }^{9}$, co może wydawać się dziwne, ponieważ poza nim, jak zauważa Tomas Venclova, nie ma w niej nic sensacyjnego ${ }^{\mathrm{IO}}$. Przypomina ona raczej kompetentne studium historycznoliterackie, w którym znaczenie ma nie tylko znajomość faktów biograficznych, ale i odwołujących się do epoki oraz nagromadzenie cennych dokumentów, listów, donosów. Dodatkowo uwagę zwracają liczne odwołania i cytaty do prac takich badaczy jak Boris Eichenbaum, Jurij Łotman, Boris Tomaszewski, Siergiej Wiesiełowski. Na szczęście cenzura nazwiskowa przestanie w latach osiemdziesiątych odgrywać tak ważną rolę jak wcześniej i pracę uda się opublikować ${ }^{\text {II }}$. Jest to jednak kolejna w dorobku twórczym Woroszylskiego książka, która przeleży w wydawnictwie kilka lat zanim zostanie opublikowana. Ważnym wątkiem poruszanym w biografii Puszkina okazuje się oczywiście cenzura, ale i „opieka”, jaką roztaczał nad nim hrabia Aleksander von Benckendorff, szef III oddziału ${ }^{\text {I2 }}$. Zarzucał on Puszkinowi, że ten nie zawiadamia go o swoich planach, na przykład o samowolnym wyjeździe na Kaukaz czy do majątku Michajłowskoje. Pisał o tym między innymi w listach do poety, pytając: „za czyim to zezwoleniem przedsięwziął Pan ową podróż” (KzP, s. 29I). Nawiązaniem do książki o autorze Eugeniusza Oniegina w tym kontekście,

9 Zob. fragment obszernego wywiadu Joanny Szczęsnej z Woroszylskim: „Pierwszy tytuł brzmiał Ten tajdak Puszkin, to był zresztą cytat z tego, jak o Puszkinie w jego czasach mówiono. Wydawca się oburzył: - Puszkin to dla nas świętość, nie możemy dawać takiego tytułu. Więc po namyśle zaproponowałem Kto zabit Puszkina, ale i to długo nie przechodziło. Dyskusje na temat tytułu wlokły się i wlokły. Proponowano mi np. Życie i dzieto Aleksandra Puszkina. Aż mnie olśnito i napisałem list do dyrektora wydawnictwa: «Szanowny panie dyrektorze! Zawiadamiam uprzejmie, że Puszkina nie zabiło KGB». I wyobraź sobie, że po tym liście oni się zgodzili" (Ja w Rosji, Rosja we mnie..., s. 10).

10 Т. Венциова, ор. cit.

11 Andrzej Friszke zwraca uwagę na dziwną politykę wydawniczą w okresie rządów gen. Wojciecha Jaruzelskiego, polegającą (obok blokady spotkań z czytelnikami i ograniczeniami, jeśli chodzi o nowe publikacje) na zezwalaniu na wznowienia książek wydanych wcześniej. Ten okres liberalizacji, obejmujący lata 1980-1981, przynosi publikacje w latach następnych, poczynając od 1982 r. Więcej zob. A. Friszke, op. cit., s. 98.

12 III Oddział Kancelarii Osobistej Jego Cesarskiej Mości to utworzony w 1826 r. (po powstaniu dekabrystów) organ tajnej policji, zajmujący się m.in. inwigilacją osób podejrzanych i śledzeniem cudzoziemców odwiedzających Rosję. 
a konkretnie do rozdziału Klatka będzie przytaczana w drugim tomie Dzienników rozmowa $\mathrm{z}$ kapitanem Kowalewskim ${ }^{\mathrm{r} 3}$, którego Woroszylski niespodziewanie, ku niezadowoleniu najbliższych zaprasza do siebie na herbatę ${ }^{\mathrm{I}}$ :

》W Wrowadziłem go do pokoju i siedliśmy w fotelach. Stanęło na herbacie, którą niebawem otrzymaliśmy. I teraz przystąpiłem do rozmowy, o którą mi chodziło. Ja: „Czytał Pan moją książkę Kto zabit Puszkina?”. On: „Przyznam, że jeszcze nie zdążyłem, ona wyszła, zdaje się, kilka miesięcy temu”. Ja: „Myślałem, że Pan czytał i świadomie nawiązuje do sytuacji tam opisanej. Za cara Mikołaja I generał hrabia Benckendorff, szef III oddziału, który «opiekował się» Puszkinem, robił mu wyrzuty, że wyjechał z Moskwy do swego majątku, nie zawiadamiając go o tym, albo że w jakimś salonie czytał swoją sztukę. Ja nie jestem Puszkinem ani pan generałem i hrabią, ale przypomniało mi się to dzisiaj, kiedy pan powiedział, żebym pana zawiadamiał z góry o swoich wieczorach autorskich...”. Uśmieszek na twarzy kapitana Kowalewskiego świadczył, że porównanie raczej mu pochlebiło, jednakże ja ciągnąłem: „Otóż muszę panu wyjaśnić, że to było możliwe w Rosji carskiej, natomiast w cywilizacji europejskiej, polskiej jest po prostu nie do pomyślenia, żeby pisarz zawiadamiał policjanta o jakichkolwiek swoich zamiarach czy pytał o pozwolenie". Powiedziałem to dosyć dobitnie, a on jakby się zmieszał [...] (Dz 2, s. 23I).

Warto w tym miejscu odnotować, że rozmowa odbyła się w maju I984 roku, a jej przebieg miał nieformalny charakter. Zaaranżowana przez pisarza, toczyła się ona bowiem nie w murach MSW, ale w przestrzeni prywatnej. Dwa lata później w rozmowie ze znajomą Woroszylski przyzna, że preferuje umówione wizyty w MSW, a nie niezapowiedziane „odwiedziny”, czyli rewizje, które kończą się rozbebeszaniem całego pokoju, stratą książek i papierów z biblioteki

13 Kapitan Kowalewski odpowiedzialny za inwigilację Woroszylskiego to tak naprawdę major Janusz Kusztelak, funkcjonariusz SB, który zajmował się m.in. sporządzaniem działań operacyjnych wobec pisarza, osaczaniem go, próbami wprowadzania w jego otoczenie agenta, co jednak okazało się niemożliwe. Więcej zob. A. Friszke, op. cit., s. 95-97.

14 Słowo „herbata” nie pojawia się tu przypadkiem. Jest to nawiązanie do przeprowadzonej 16 lutego $1984 \mathrm{r}$. rewizji w mieszkaniu Woroszylskiego, podczas której sfilmowano zawartość szafy (z pudełkiem herbaty Lipton na pierwszym planie) oraz skonfiskowano sto trzynaście książek, co Woroszylski skomentował w wysłanym nazajutrz liście do generała Kiszczaka: „ludzie w Polsce nigdy nie dali się przekonać do poglądu, obcego naszej kulturze i poczuciu prawnemu, że może istnieć jakaś literatura «zakazana», której czytania i posiadania powinni się wystrzegać. Tym bardziej trudno się spodziewać, że pisarz będzie cenzurował własną bibliotekę i usuwał z niej poezje, eseje, powieści, książki z dedykacjami przyjaciół w lęku przed ich «niebłagonadiożnostią»”. Cyt. za: ibidem, s. 94-95. 
oraz uczuciem obrzydzenia wobec zbezczeszczonej przestrzeni, w której trudno się odnaleźć. A poza tym: ,jestem pisarzem i w tych rozmowach, jakkolwiek też pozostaje po nich niemiły osad, coś mnie jednak ciekawi, za dużo byłoby powiedzieć: pociąga. W sumie wydaje mi się, że w tym wariancie moje koszta psychiczne są mniejsze...” (Dz 2, s. 513).

Oczywiście, podobnie jak we wcześniejszych książkach biograficznych, również w tej poświęconej Puszkinowi znajdziemy liczne paralele między cenzurą carską a peerelowską, między reżimem carskim a komunistycznym, między dekabrystami a dysydentami ${ }^{15}$. Ich śledzenie nieodwołalnie wzbudza refleksję o podobieństwie mechanizmów działania cenzury i aparatu represji w tych odmiennych rzeczywistościach, ale nietrudno zauważyć i zasadnicze różnice, wynikające ze służebnej roli pisarzy rosyjskich w XIX wieku wobec carskiego dworu (o czym będzie jeszcze mowa w związku z wykładami prowadzonymi przez Woroszylskiego w ramach Towarzystwa Kursów Naukowych) oraz niezależności wewnętrznej i buntu twórców w okresie PRL-u, czemu autor Literatury dał wyraz w przywołanej już rozmowie $z$ cenzorem.

Starając się unikać otwartej konfrontacji z cenzurą, Woroszylski walczył o wydawanie swoich utworów, ale także redagowanych i współredagowanych antologii, żeby nie dopuścić do sytuacji opisanej w drugim tomie Dzienników, a dotyczącej Antologii poezji żydorwskiej w wyborze Salomona Łastika i Arnolda Słuckiego. Książka była gotowa do druku w roku I968, ale z oczywistych względów wydanie jej wtedy okazało się niemożliwe, co spowodowało długotrwałe zawieszenie publikacji. Ukazuje się ona dopiero w 1983 roku, już po śmierci Łastika, Słuckiego i innych tłumaczy, co Woroszylski kwituje następującym wyznaniem z 30 listopada I983 roku: „tak przez wiele lat - aż dopiero teraz. Tymczasem dalsi tłumacze poumierali. Cmentarz pomnożony przez cmentarz. Nie mówię już o cmentarzu moralnym bo jak określić obecność w książce ludzi, którzy następnie zdeklarowali się jako antysemici” (Dz 2, s. 16I). Na szczęście antologia zawierająca utwory stu trzech poetów żydowskich w przekładach pięćdziesięciu dziewięciu poetów polskich, wśród których znajdziemy nazwisko Woroszylskiego ${ }^{16}$, choć wydana dopiero po piętnastu latach, bardzo szybko, bo już w I986 roku, zostanie wznowiona.

15 Т. Венциова, ор. cit.

16 Woroszylski przetłumaczył poemat Chaima Nachmana Bialika $W$ mieście rzezi, który powstał pod wpływem pogromu w Kiszyniowie w 1903 r. W zapiskach przy tej okazji znajdziemy dość istotne z punktu widzenia utrwalania przez pisarzy doświadczeń granicznych wyznanie autora Literatury z 5 marca 1966 r.: „Rano ukończyłem tłumaczenie poematu Bialika o pogromie. Tłumaczyłem to z męką, niechęcią, wbrew sobie - nie ze względu na konieczność posługiwania się «rybką» i nie przez straszliwą materię dzieła (pogrom). Raziło wielosłowie, uparta chęć powiedzenia przez autora tego, czego nie da się powiedzieć i opowiedzieć, wyrażenia uczuć zgrozy, tragizmu, zwątpienia w ludzkość za pomocą wielu słów, okrzyków, obrazów etc. Poeci ówcześni nie wpadli jeszcze na to, że doświadczenie ludobójstwa opiera się takiej poetyzacji 
Ciekawa jest w tym kontekście historia publikacji Antologii nowoczesnej poezji rosyjskiej 1880-1967, nad którą prace trwały w latach sześćdziesiątych (wysyłka do Ossolineum następuje 25 listopada I966 roku - Dz I, s. 213), ale wydana została dopiero w 1971 roku (chociaż z perspektywy wspomnianej Antologii poezji żydowskiej trzeba przyznać, że przestój nie trwał zbyt długo). Interesujący jest tutaj dobór autorów. Znajdziemy wśród nich tak zaskakujące nazwiska jak Daniił Charms, Osip Mandelsztam czy Josif Brodski. Okazuje się przy tym, że na przeszkodzie w drodze do publikacji stanęły nie tyle zgromadzone utwory czy nazwiska twórców (chociaż trzeba było postarać się o fikcyjne adresy bibliograficzne, jeśli chodzi o ich wydanie w ZSRR, do którego w wielu przypadkach w ogóle nie doszło), ile noty o autorach - lakoniczne, a przez to jeszcze bardziej skupione na tragizmie ich egzystencji, pokrywającym się z latami terroru, o których nie można było wspominać. Potwierdza to poniższa uwaga:

》 Opracowanie to budziło zastrzeżenia z powodu szczególnego zestawu not biograficznych opracowanych przez W[iktora] Woroszylskiego, eksponujących informację o aresztowaniach, śmierci w niewyjaśnionych okolicznościach, zaginięciu wielu poetów radzieckich itp., jak i ze względu na osobę W[iktora] Woroszylskiego, który książkę zaopatrzył wstępem (wg informacji przekazanej nam przez dyrektora „Ossolineum” - pozycja ta została zmatrycowana i po pewnym czasie wydawnictwo zamierza powrócić do tej sprawy ${ }^{17}$.

O reakcji na publikację Woroszylski niestety nie pisze w Dziennikach - notatki prowadzone między marcem 1968 a sierpniem 1979 roku nie zachowały się. Można jednak przypuszczać, że poczuł on zdecydowaną ulgę. W zapiskach diarystycznych z I966 roku znajdziemy niejedną uwagę na temat mozolnej pracy nad gromadzeniem i tłumaczeniem tekstów do antologii. Co ciekawe, wśród tłumaczy pojawiają się nierzadko te same nazwiska, co w przypadku Antologii poezji żydowskiej, ale oprócz tego mamy na liście osoby, które trudno byłoby skojarzyć z dokonaniami translatorskimi w obrębie poezji rosyjskiej: Leszek Kołakowski czy Robert Stiller.

Antologia ta ma jednak istotne znaczenie z punktu widzenia zmagań z cenzurą. Udało się bowiem nie tylko unaocznić zakładaną ciągłość i różność nowoczesnej poezji rosyjskiej ( $\mathrm{z}$ wypełnieniem luki widocznej w jej obrazie w latach trzydzie-

bardziej od innych doświadczeń ludzkich. Po ostatniej wojnie powstała Różewiczowska poetyka ściśniętego gardła, jedynie adekwatna (czasami) do takiego tematu. Po niej z kolei powrót do tamtej jakoś obraża wrażliwość ludzką i poetycką" (Dz 1, s. 200).

17 D. Jarosz, Dzieje książki w Polsce 1944-1989. Wybór źródet, Warszawa 2010, http://www.sbp.pl/wydawnictwa/archiwum_cyfrowe/pdf/?book_id=2359 (stan z 4 września 2018 r.). 
stych, spowodowanej zniknięciem wielu nazwisk), opublikować nieznane utwory znanych twórców, ale też przeforsować projekt, w którym należne miejsce znaleźli tacy poeci jak Nikołaj Gumilow, Osip Mandelsztam czy wreszcie członkowie ugrupowania Oberiu: Konstantin Waginow, Aleksandr Wwiedienski, Daniił Charms, Nikołaj Olejnikow i Nikołaj Zabołocki. Szczególnej wagi w kontekście doboru nazwisk poetów i niemożności napisania wprost o specyfice ich poezji nabierają często przewijające się przez noty informacje o dorobku translatorskim i utworach adresowanych do dzieci, występujące wszak jako substytut oryginalnej, ale nieistniejącej oficjalnie twórczości. Zdarzają się w antologii wiersze zaskakujące z punktu widzenia nieingerencji cenzorów. Jednym z nich jest utwór Zabołockiegо Где-то в поле возле Магадана, który powstał dwa lata przed śmiercią poety w 1956 roku. Oczywiście w nocie o autorze nie pojawia się nawet wzmianka o tym, że był on więźniem Gułagu i że wiersz, który w przekładzie Dąbrowskiego i Woroszylskiego nosi tytuł Gdzieśs pod Magadanem..., odnosi się do łagrowych przeżyć Zabołockiego. A jednak trudno przeoczyć wymowny przekaz zawarty w dwóch ostatnich strofach:

\section{\Stanął koń i praca się skończyła, \\ Nastał kres nareszcie dniom tułaczym... \\ Słodka senność starców otuliła \\ I w daleki kraj powiodła z płaczem.}

Już się w ręce straży nie dostaną,

Nigdy nie dopadną ich pogonie,

Tylko gwiazdozbiorów Magadanu

Światłość nad głowami ich zapłonie.

$$
\text { (A 2, s. 207) }
$$

Podobnie rzecz się ma z wierszem Olgi Bergholc Aленушка z I940 roku. Na jednym $\mathrm{z}$ wykładów prowadzonych w ramach Towarzystwa Kursów Naukowych Woroszylski opowiedział o okolicznościach powstania tego utworu, zwracając uwagę słuchaczy na zaszyfrowany komunikat. $Z$ pozoru mamy do czynienia $\mathrm{z}$ baśniową konwencją (stąd decyzja tłumacza o oddaniu imienia bohaterki i zarazem tytułu wiersza po polsku jako Kasieńka), tak naprawdę jednak utwór Bergholc wyraża w zakamuflowany sposób żałobę po mężu, który stał się ofiarą represji lat trzydziestych i zginął w więzieniu. Ofiarą była i sama Bergholc, która straciła, jak się okazuje, nie tylko męża, ale i dwoje dzieci, ale ponieważ przeżyła, uznała za stosowne pozostawić znak, ślad po tych wydarzeniach, ukrywając go głęboko w wierszu, będącym lamentem Alionuszki-Kasieńki nad zmarłym Iwanuszką-Jasieczkiem: 
Jasieczku, kochaneczku, najdroższy mój, najbliższy, zgubiony, utopiony to ja, to ja, czy słyszysz?

Skrzywdzili, zbezcześcili, wydali cię na męki Jasieczku, kochaneczku, czy wrócisz do Kasieńki?

(A 2, s. 278)

Wiersze Bergholc zamieszczone w antologii - podobnie zresztą jak utwory innych poetów - kryją o wiele więcej zaszyfrowanych znaków rzeczywistości, o której nie można było pisać wprost. Temat ten, zainspirowany pracą doktorską Michaiła Hellera Świat obozów koncentracyjnych a literatura sowiecka, opublikowaną w I974 roku w Paryżu przez Instytut Literacki, stanie się jednym z ważniejszych, jeśli chodzi o cykl wykładów prowadzonych w ramach TKN. Mowa o prelekcji dotyczącej świata koncentracyjnego i dwóch strategii jego opisu. Pierwszą jest pełna otwartość i bezkompromisowość wobec opresyjności systemu, tematów tabu i zakazanych rejestrów rzeczywistości, co skutkować może jedynie pisaniem do szuflady z nadzieją, że nadejdą czasy, w których będzie można te utwory opublikować jako „bezpośrednie” świadectwa tamtych wydarzeń, „mowy” oskarżycielskie o wielkiej sile rażenia. Jest też jednak inna strategia i inne, „pośrednie”, hybrydyczne świadectwa, które nie muszą czekać na publikację, ale są skierowane do uważnego i kompetentnego czytelnika, badacza czy tłumacza, który je rozszyfruje, odkoduje ukryte informacje dotyczące mylącej konwencji, rzeczywistych przyczyn posłużenia się liryką maski. I do takich świadectw należy właśnie poezja Bergholc, której Woroszylski poświęca sporo uwagi, przeciwstawiając ją liryce Anny Achmatowej czy prozie Lidii Czukowskiej.

Warto również podkreślić, że wspomniane już Towarzystwo Kursów Naukowych, powstałe w styczniu 1978 roku, to jeszcze jeden ważny front walki z cenzurą, którą Woroszylski w latach siedemdziesiątej toczył już otwarcie (członkiem TKN został w lutym 1978 roku). Obok między innymi Jerzego Jedlickiego, Bohdana Cywińskiego, Władysława Bartoszewskiego, Adama Michnika, Jacka Kuronia był wykładowcą i prowadził w swoim warszawskim mieszkaniu na Żoliborzu kurs zajęć Wybrane zjawiska i problemy nowszej literatury rosyjskiej ${ }^{\mathrm{I8}}$. Wśród tematów, które znalazły się 
$\mathrm{w}$ centrum zainteresowania Woroszylskiego, warto wymienić fenomen inteligencji rosyjskiej rozpatrywany w aspekcie właściwego jej poczucia długu do spłacenia wobec ludu, ale i odmowy służby; problem profesjonalizacji literatury rosyjskiej w pierwszej połowie XIX wieku i decyzji twórców o rezygnacji ze służby na rzecz państwa, mecenatu i protekcji, a w konsekwencji kroku w kierunku niezależności zawodowej, finansowej, społecznej i politycznej; charakterystykę modernizmu, akmeizmu, futuryzmu i późniejszych ugrupowań literackich widzianych z punktu widzenia wspomnianej przy okazji wstępu do Antologii norwoczesnej poezji rosyjskiej ciągłości procesu literackiego oraz inspirującej idei współzawodnictwa; problem utopii i antyutopii w literaturze rosyjskiej, zjawisko dawnego i nowego panmongolizmu, wnikliwe studium nurtu słowianofilskiego i różnych reakcji na niego, charakterystykę ugrupowania Oberiu, a także ich absurdalnej wizji rzeczywistości, a na drugim biegunie - demonicznego oglądu rzeczywistości, tragigroteski na przykładzie prozy Michaiła Bułhakowa (obie te wizje Woroszylski wysnuwa z tradycji Nosa Nikołaja Gogola), czy wreszcie zjawisko degrengolady literatury w latach trzydziestych i prób jej przezwyciężenia. Co zrozumiałe, wśród poruszanych zagadnień nie brakuje tematów neutralnych, ujęć historycznoliterackich o charakterze syntetyzującym, ale są i takie, których trudno nie uznać za oskarżycielskie. Pojawiają się w nich takie słowa jak „łagry”, „represje”, ,czystki”, „unicestwienie”, ,masowe morderstwa”, „przesiedlenia”, „despotyzm”, ,jeżowszczyzna”, „żdanowszczyzna”mowa szczególnie o świecie koncentracyjnym, oberiutach czy właśnie nasilającym się ,rozkładzie”, pogromie literatury rosyjskiej, dla której otrzeźwieniem, wytrąceniem z letargu, z karlenia okazała się Wielka Wojna Ojczyźniana. Wiele w tych wykładach błyskotliwych i przenikliwych analiz, wiele aforyzmów i trafnych tez.

Jako przykład mogą posłużyć rozważania dotyczące szuflady, w interesujący sposób korespondujące ze strategiami opisu świata koncentracyjnego. Woroszylski wspomina o szufladzie rozumianej dosłownie jako miejsce do przechowywania utworów, które nie ujrzą światła dziennego, o schowkach, dołach, kryjących teksty mogące w tamtych okolicznościach ściągnąć na autorów i ich bliskich realne niebezpieczeństwo. Mówi też jednak o „szufladzie pamięci”, w której na przykład Nadieżda Mandelsztam przechowywała wiersze męża. Niemniej ciekawa wydaje

rażam w tym miejscu ogromną wdzięczność, korzystam z wersji roboczej, przygotowywanej do publikacji. Warto wspomnieć, że kompetencje Woroszylskiego w zakresie znajomości biografii twórczej Majakowskiego i Jesienina zostaną wykorzystane przez twórców fundamentalnego, zawierającego trzy tomy, opracowania w języku francuskim, poświęconego historii literatury rosyjskiej XX wieku. Pisarz jest autorem dwóch rozdziałów w drugim tomie, obejmującym okres rewolucji i lat dwudziestych. O tym, że jest to bardzo prestiżowe wydanie, świadczy chociażby dobór nazwisk twórców poszczególnych rozdziałów, wśród których są takie znane w rusycystyce międzynarodowej nazwiska jak Jefim Etkind, Georges Nivat, Vittorio Strada, Lew Łosiew, Michaił Heller, Andrzej Drawicz, Tomas Venclova, Ryszard Przybylski, Ilja Serman. Więcej zob. Histoire de la littérature russe. Le XXe siècle, éd. E. Etkind, G. Nivat, I. Serman, V. Strada, Paris 1988. 
się myśl o istnieniu szuflady potencjalnej, „mieszczącej” teksty nieistniejące, ale zaprojektowane, dojrzewające w głowie świadków. I tu jako przykład znów wskazuje na żonę Mandelsztama i jej Wspomnienia, podkreślając ich epokowe znaczenie. A przy okazji konstatuje, że w wielu przypadkach już nie jesteśmy w stanie ustalić, ilu takich realnych i potencjalnych szuflad można by się było doliczyć. Na szczęście w literaturze rosyjskiej (podobnie jak w polskiej) pojawił się w pewnym momencie drugi obieg, który w realiach dwudziestowiecznych stał się elementem wyzwolenia pisarzy ze służebnej roli wobec partii oraz niszczycielskiej siły cenzury. Tym samym w cyklu wykładów następuje powrót do pierwszego z nich, w którym ważne miejsce przypadło Puszkinowi jako patronowi tych wszystkich, którzy do końca walczą o wolność, godność i niezależność. W ostatnim wykładzie z kwietnia I979 roku Woroszylski porusza kwestie związane z określonym modelem losu poetów rosyjskich (poczynając od autora Eugeniusza Oniegina), zakładającym odrębność, wyobcowanie i tragizm. Nawiązuje tu przy okazji do własnej książki, która - jak zauważa - nie może zostać wydana z przyczyn od niego niezależnych. Relacjonuje najważniejsze rozdziały, w tym szczególnie rozdział Klatka oraz Kto zabit Puszkina, i na koniec rozszerza właściwie noty o autorach zgromadzone w Antologii nowoczesnej poezji rosyjskiej, zwracając uwage na to, jak wielu utalentowanych twórców zginęło w tragicznych okolicznościach. Nic dziwnego, że tematyka wykładów prowadzonych w ramach TKN wzbudzała zainteresowanie partii i jej reakcję, wiele z nich dotyczyło bowiem zakazanych treści. Wykładowcy byli poddawani różnym formom represji. W grę wchodziły zatrzymania, rewizje, grzywny oraz (w łagodniejszej wersji) zakłócanie wykładu przez aktywistów należących do Związku Socjalistycznej Młodzieży Polskiej czy Służby Bezpieczeństwa. Nie inaczej było w przypadku Woroszylskiego. Nie tylko został on zatrzymany i7 lutego I979 roku w Krakowie, gdzie miał poprowadzić zajęcia, wskutek czego do spotkania ze studentami nie doszło, ale dwa miesiące później, 26 kwietnia 1979 roku, w jego mieszkaniu doszło do incydentu. Jak relacjonuje Friszke, oprócz dwunastu słuchaczy, którzy uczęszczali na zajęcia regularnie, w domu pojawiło się około dwudziestu nowych osób:

INa pytanie gospodarza, skąd są, odpowiedzieli, że z SGPiS, Politechniki i Huty Warszawa. Gdy na początku zajęć Woroszylski chciał oddać głos studentowi, który przygotował referat o Trifonowie, przybysze zaprotestowali i zażądali dyskusji: „Chcemy podyskutować o związkach TKN z Wolną Europą". Wezwali do ułożenia listu przeciw Wolnej Europie, który Woroszylski powinien podpisać. „Mimo apeli moich i innych osób o dopuszczenie do wygłoszenia referatu, a następnie - o opuszczenie mieszkania, grupa nie zdradzała chęci zaprzestania 
swojej akcji i usiłowała narzucić mi «dyskusję» na temat mojej osoby i złowrogiej roli TKN (który ma - wedle rzekomego oświadczenia Jacka Kuronia - zmierzać do rozlewu krwi).W tej sytuacji opuściłem swój gabinet wraz z większością normalnych słuchaczy; ktoś tylko pozostał, żeby dotrzymać przybyszom towarzystwa. Wygłaszali oni dalej swoje przygotowane teksty, pozostając w moim mieszkaniu łącznie nieco ponad półtorej godziny. Po upływie tego terminu przywódca grupy, 3o-letni (albo starszy) mężczyzna w szarym garniturze, dał sygnał i cała dwudziestka wyszła”. Po ich wyjściu Woroszylski poprowadził zajęcia ${ }^{\text {I9. }}$.

Działalność TKN zakończyła się definitywnie wraz z ogłoszeniem stanu wojennego, ale już od roku akademickiego 1979/ı980 zajęcia prowadzono jedynie w kameralnych grupach, zrezygnowano natomiast ze spotkań z udziałem publiczności, uczestników spoza grup seminaryjnych.

Ostatnią odsłoną rozważań nad rolą cenzury w życiu i działalności nie tylko Woroszylskiego, o której warto wspomnieć, jest spotkanie w Radziejowicach, odbywające się już w innej rzeczywistości, w kwietniu I99o roku ${ }^{20}$. Woroszylski jako koordynator ze strony polskiej opisuje w Dziennikach dość szczegółowo przygotowania do tego wydarzenia - rozmowy i pertraktacje $z$ Rosjanami, ustalanie listy uczestników z obu stron, wątpliwości co do zasadności i charakteru tej debaty (określonej jako polsko-radziecki okrągły stół literacki), skutkujące wycofaniem się niektórych zaproszonych gości po stronie polskiej tuż przed spotkaniem ${ }^{2 \mathrm{I}}$. Rozmowa polskich i rosyjskich pisarzy, i ich namysł nad relacjami Polski i Rosji, nad poszukiwaniem wspólnego języka w epoce wstrząsów i perturbacji politycznych, choć zasadniczo projektowana jako zwrot w przyszłość, w postawienie diagnozy, co utrudnia porozumienie, to jednak niepozbawiona była refleksji o odległej i niedawnej przeszłości. Nie tylko mówi się o tym, że wcześniej nie mogłoby tak po prostu do niej dojść, że byłaby zgromadzeniem nielegalnym, ale i nierealnym, patrząc na liczbę uczestników. Podczas otwarcia obrad Woroszylski zwraca uwagę na literaturę powstającą w danym miejscu i czasie, która jest językiem i która nieustannie nam o czymś mówi, czy to bezpośrednio, czy też pośrednio:

19 A. Friszke, op. cit., s. 83. Jak wspomina Natalia Woroszylska, z grupą aktywistów w gabinecie pisarza pozostał Adam Pomorski.

20 Polskę reprezentowali: Maria Janion, Irena Lewandowska, Jacek Bocheński, Andrzej Drawicz, Michał Jagiełło, Tadeusz Konwicki, Rafał Marszałek, ks. Janusz Pasierb, Adam Pomorski, Wiktor Woroszylski, Zbigniew Żakiewicz. Uczestnikami ze strony rosyjskiej byli z kolei: Natalia Iwanowa, Junna Moric, Ksenia Starosielska, Siergiej Awierincew, Oleg Czuchoncew, Fazil Iskander, Wiktor Jerofiejew, Wiaczesław Piecuch, Jewgienij Popow, Anatolij Pristawkin.

21 Będą one dostępne dla czytelnika w trzecim tomie Dzienników, obejmującym lata 1988-1996. 
\ Komunikuje coś o sobie samej i o glebie, z której powstała - przez dobór tematów, wątków, fabuł, postaci, preferencję dla takich, a nie innych gatunków, przez uprawiane style, przez pojęcia-klucze, przez swoje natręctwa, a także przez pominięcia, tabu, kamuflaże, sytuacje zastępcze - przez to wszystko i nie tylko to literatura jest językiem swojego czasu, swojego narodu w tym akurat miejscu jego drogi dziejowej, językiem przemawiającym nie tylko do swojego zasadniczego, głównie rodzimego adresata, ale i do tego innego, „obcego”, który ciekaw jest społeczeństwa mówiącego literaturą [...], bywa nim nawet jakoś zafascynowany, pragnie je poznać i zwraca się ku temu właśnie źródłu, próbuje zrozumieć ten właśnie język, co nie zawsze jest takie proste, bo każdy język i literatura jako język także zawiera przecież element szyfru, tajemnicy, nieprzetłumaczalnego idiomu, nie w sensie filologicznym, ale w sensie doświadczenia, które w nim się kryje ${ }^{22}$.

Mamy wrażenie, że przez tę wypowiedź pisarza przemawiają osobiste doświadczenia literackie i translatorskie. Przemawia przede wszystkim chęć zwrócenia uwagi na istotne niuanse, na wymuszone okolicznościami przemilczenia, zafałszowania, uniki, deformacje. Niestety, co przyzna Woroszylski w przemówieniu podsumowującym spotkanie, temat ten zostanie zaledwie zasygnalizowany w wypowiedziach uczestników, które zdominuje jednak sprawa polsko-rosyjskich relacji, pretensji i skarg, raczej różnic niż podobieństw, osadzonych na szczęście głęboko w kontekście historycznym, co powoduje, że stanowią one udaną próbę pokazania pewnych mechanizmów zachowań stereotypowych, ich genezy. Co istotne, nie ma w tych wypowiedziach intelektualistów, cienia cenzurowania własnych myśli, jest natomiast autentyczna chęć przyjrzenia się trudnym relacjom, przekładająca się na stawianie ważnych i odważnych pytań. W tym sensie debata radziejowicka wciąż pozostaje niezmiernie aktualnym zbiorem refleksji i wątpliwości dotyczących kwestii fundamentalnych z punktu widzenia relacji polsko-rosyjskich.

Mocnymi argumentami w rozmowie po stronie polskiej były w Radziejowicach przywołane starania i zasługi opozycjonistów, by nawet w najtrudniejszych czasach promować literaturę i kulturę rosyjską. Nic dziwnego, że wspomina się o drukowaniu utworów niektórych rosyjskich twórców w Polsce wcześniej, niż nastąpiło to w ZSRR (Brodski, Pristawkin), o tutejszych światowych debiutach (casus Ajgiego, wypromowanego przez Woroszylskiego), o wydawnictwach drugiego obiegu,

22 Szukanie wspólnego jezyka. Rozmowa pisarzy polskich i rosyjskich w Radziejowicach 24 i 25 kwietnia 1990, oprac. W. Woroszylski, „Więź” 1990, nr 10, s. 5-6. 
w których publikowane były teksty współczesnych pisarzy rosyjskich - wydane, co podkreślał Andrzej Drawicz, „wówczas, kiedy groziło za to więzienie, grzywna, prześladowania”23.

Tak naprawdę jednak zapis debaty radziejowickiej każe zastanowić się nad tym, czy omówione marginesowo zagadnienie literatury jako języka, w tym języka ezopowego to rzeczywiście problem tylko przeszłości, to jest tekstów pisanych w Rosji carskiej i w ZSRR oraz w PRL-u? Czy wywołany przez Woroszylskiego i Iwanową czytelnik, który był „współuczestnikiem procesu twórczego”, rozszyfrowującym „aluzje, realia historyczne, paralele” ${ }^{24} \mathrm{w}$ tamtych czasach, dziś nie miałby już racji bytu? Albo miałby tylko w odniesieniu do pojawiających się wciąż świadectw czasów minionych, wyciąganych z szuflad i schowków? Doświadczenie współczesnej literatury rosyjskiej przekonuje nas, że gra, ale i walka $z$ cenzurą i autocenzurą to wciąż problem niezwykle aktualny.

\section{Bibliografia:}

Antologia poezji żydowskiej, wybór, noty oraz przypisy S. Łastik, red. i słowo wstępne A. Słucki, Warszawa 1983; Dąbrowski W., Mandalian A., Woroszylski W., Antologia nowoczesnej poezji rosyjskiej 1880-1967, t. 1-2, Wroclaw 1971;

Friszke A., Wiktor Woroszylski. Polityka i literatura, w: W. Woroszylski, Dzienniki 1953-1982, t. 1, Warszawa 2017;

Histoire de la littérature russe. Le XXe siècle, éd. E. Etkind, G. Nivat, I. Serman, V. Strada, Paris 1988;

Hobot J., Gra z cenzurą w poezji Nowej Fali (1968-1976), Kraków 2000;

Ja w Rosji, Rosja we mnie. Wiktor Woroszylski w rozmowie z Joanna Szczęsną, „Gazeta Wyborcza” z 6-8 kwietnia 1996 r.;

Jarosz D., Dzieje ksiązki w Polsce 1944-1989. Wybór źródet, Warszawa 2010, http://www.sbp.pl/wydawnictwa/ archiwum_cyfrowe/pdf/?book_id=2359;

Kandziora J., „Literatura” Wiktora Woroszylskiego - poetycka formuta prozy autobiograficznej, „Pamiętnik Literacki” 1992, z. 1;

Olaszek J., Wołk G., Drugi obieg wydawniczy w oczach Stużby Bezpieczeństwa, „Pamięć i Sprawiedliwość” 2013, nr 12/1(21), s. 369-435, http://bazhum.muzhp.pl/media//files/Pamiec_i_Sprawiedliwosc/Pamiec_i_Sprawiedliwosc-r2013-t12-n1_(21)/Pamiec_i_Sprawiedliwosc-r2013-t12-n1_(21)-s369-435/Pamiec_i_Sprawiedliwosc-r2013-t12-n1_(21)-s369-435.pdf;

Pawletko B., Wiktora Woroszylskiego spotkania z Rosją, „Przegląd Rusycystyczny” 2012, nr 1-2;

Szukanie wspólnego jezzyka. Rozmowa pisarzy polskich i rosyjskich w Radziejowicach 24 i 25 kwietnia 1990, oprac. W. Woroszylski, „Więź” 1990, nr 10;

Venclova T. , Puszkin kak nieizbieżnyj „drugoj”, „Inostrannaja litieratura” 2009, nr 4, http://magazines.russ.ru/

23 Ibidem, s. 18. Na temat wydawnictw drugiego obiegu i wykazu publikacji zob. J. Olaszek, G. Wołk, Drugi obieg wydawniczy w oczach Stużby Bezpieczeństwa, „Pamięć i Sprawiedliwość” 2013, nr 12/1(21), s. 369-435, http://bazhum.muzhp.pl/media//files/Pamiec_i_Sprawiedliwosc/Pamiec_i_Sprawiedliwosc-r2013 -t12-n1_(21)/Pamiec_i_Sprawiedliwosc-r2013-t12-n1_(21)-s369-435/Pamiec_i_Sprawiedliwosc-r2013-t12-n1_(21)-s369-435.pdf(stan z 15 września 2018 r.).

24 Szukanie wspólnego jezyka..., op. cit., s. 73. 
inostran/2009/4/ve5-pr.html;

Watała E., Woroszylski W., Życie Sergiusza Jesienina, Warszawa 1983;

Woroszylski W., Dzienniki 1953-1982, t. 1, Warszawa 2017;

Dzienniki 1983-1987, t. 2, Warszawa 2018;

Ja - ̇ertwa russkoj litieratury (Intierwju wziała Tatiana Bek), „Woprosy litieratury” 1995, nr 2.

Kto zabit Puszkina, Warszawa 2004;

Moi Moskale. Wybór przektadów z poezji rosyjskiej od Puszkina do Ratuszyńskiej, Wrocław 2006;

Sny pod śniegiem, Warszawa 1963;

Życie Majakowskiego, Warszawa 1984;

SŁowa klucze: Wiktor Woroszylski, cenzura, relacje polsko-rosyjskie, Towarzystwo Kursów Naukowych

\section{БЕАТА ПАВ АЕТКО}

О АИТЕРАТУРНЫХ И ПЕРЕВОАЧЕСКИХ ПРЕНИЯХ ВИКТОРА ВОРОШИАЬСКОГО С ЦЕНЗУРОЙ (НА ФОНЕ ДНЕВНИКОВ)

Публикация, Аневников Виктора Ворошильского заставцяет заново перечитать его произведения и посмотреть на его переводческие опыты и достижения в более широком контексте. Поводом Аля этого явАяются описанные им в Аневнике столкновения с цензурой, постоянные уловки, стратегии, но также и компромиссы, на которые ему приходицось иАти, что вАияло на итоговый виА и сроки публикации, например, Антологии современной русской поэзии г880-1967 годов. Особенное

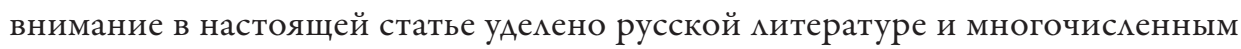
переводам писателя, т.е. той сфере творческой деятельности, которая Аишь на первый взгляд казалась удобным способом продолжать печататься. Читая Аневниковые записи, мы убежАаемся, что иногда не имело значения, кого именно Ворошильский переводиц: отказ от публикации вызывала сама его фамилия. В статье автор касается не только Аневниковых «кулис» создания митературных биографий и переводов, но и Аекций о русской Аитературе, которые Ворошильский читац в Обществе научных курсов, и встречи польских и русских писателей в Радзеевицях.

КАЮчеВЫЕ САОВА: Виктор Ворошильский, цензура, польско-русские связи, Общество научных курсов 


\section{Beata Pawletko}

\section{ON WIKTOR WOROSZYLSKI'S LITERARY AND TRANSLATIONAL SKIRMISHES WITH THE CENSORSHIP (WITH THE DIARIES IN THE BACKGROUND)}

The publication of Wiktor Woroszylski's Dzienniki (Diaries) encourages one to reread his pieces, but also to present a wider, contextual depiction of his undertakings and translational accomplishments. In respect of this, the pretext are the struggles with censorship as recorded in the diaries, the everyday evasions and strategies, but also the compromises which one had to make, all of which had a direct influence on the final form and timing of publication of, for example, Antologia nowwoczesnej poezji rosyjskiej I880-1967 [An Anthology of Modern Russian Poetry I880-1967]. An area of special interest in the present article is Russian literature and numerous translations, that is those areas of creative endeavour which only seemingly appeared to be comfortable ways of remaining within the publishing circuits. Upon reading the diary notes we realise that, with time, it no longer matters who Woroszylski is translating - just his surname is significant enough that it predetermines a refusal to publish. In the present article, the author relates not only to the behind-the-scenes of the origins of literary biographies and translations based on the diaries. The author also refers to the lectures on Russian literature given as part of the Towarzystwo Kursów Naukowych [The Academic Courses Association], as well as the meetings of Polish and Russian writers in Radziejowice.

Keywords: Wiktor Woroszylski, censorship, Polish-Russian relations, Towarzystwo Kursów Naukowych [The Academic Courses Association] 